References and links

ORIGINAL RESEARCH PAPERS Guarente, L., Nye, J. S.

Hochschild, A. \& Ptashne, M. Mutant lambda phage repressor

with a specific defect in its positive control function. Proc. Nat Acad. Sci. USA 79, 2236-2239 (1982)| Hochschild, A., Irwin, N. \& Ptashne, M. Repressor structure and the mechanism of positive control. Cell 32, 319-325 (1983) | Li, M., Moyle, H. \& Susskind, M. M. Target of the transcriptional activation function of phage lambda cl protein. Science 263, 75-77 (1994) Zhou, Y., Zhang, X. \& Ebright, R. H. Identification of the activating region of catabolite gene activator protein (CAP): isolation and characterization of mutants of CAP specifically defective in transcription activation. Proc. Natl Acad. Sci. USA 90, 6081-6085 (1993) | Chen, Y., Ebright, Y. W. \& Ebright, R. H. Identification of the target of a transcription activator protein by protein-protein photocrosslinking. Science 265, 90-92 (1994)

FURTHER READING Brent, R. \& Ptashne, M. A eukaryotic transcriptional activator bearing the DNA specificity of a prokaryotic repressor. Cell 43, 729-736 (1985) | Keegan, L., Gill, G. \& Ptashne, M. Separation of DNA binding from the transcription-activating function of a eukaryotic regulatory protein. Science 231, 699-704 (1986) | Igarashi, K. \& Ishihama, A. Bipartite functional map of the $E$. coli RNA polymerase alpha subunit: involvement of the $\mathrm{C}$-terminal region in transcription activation by cAMP-CRP. Cell 65, 1015-1022 (1991) | Blatter, E. E., Ross, W., Tang, H., Gourse, R. L. \& Ebright, R. H. Domain organization of RNA polymerase alpha subunit: C-terminal 85 amino acids constitute a domain capable of dimerization and DNA binding. Cell 78, 889-896 (1994) Benoff, B. et al. Structural basis of transcription activation: the CAP-alpha CTD-DNA complex. Science 297, 1562-1566 (2002) | Ptashne, M. \& Gann, A. Genes \& Signals (Cold Spring Harbor Laboratory Press, New York, 2002) | Jain, D., Nickels, B. E., Sun, L., Hochschild, A. \& Darst, S. A. Structure of a ternary transcription activation complex. Mol. Cell 13, 45-53 (2004)

important roles in mammalian physiology, growth and behaviour, and numerous diseases are associated with imprinting defects. Beyond their function, imprinted genes are appreciated as a useful and important model for the study of epigenetic regulation of gene expression, because they provide a natural system in which epigenetic modifications are the main determinants of a functional state.

Emily Niemitz, Associate Editor, Nature Genetics

\section{References and links}

ORIGINAL RESEARCH PAPERS Surani, M. A. H., Barton, S. C. \& Norris, M. L. Development of reconstituted mouse eggs suggests imprinting of the genome during gametogenesis. Nature 308, 548-550 (1984) | McGrath, J. \& Solter, D. Completion of mouse embryogenesis requires both the maternal and paternal genomes. Cell 37, 179-183 (1984) | Bartolomei, M. S., Zemel, S. \& Tilghman, S. M. Parental imprinting of the mouse H19 gene. Nature 351, 153-155 (1991)|Barlow, D. P., Stoger, R.

Hermann, B. G., Saito, K. \& Schweifer, N. The mouse insulin-like growth factor type-2 receptor is imprinted and closely linked to the Tme locus. Nature 349, 84-87 (1991) | DeChiara, T. M.,

Robertson, E. J. \& Efstratiadis, A. Parental imprinting of the mouse insulin-like growth factor II gene. Cell 64, 849-859 (1991) FURTHER READING Bartolomei, M. S., Webber, A. L., Brunkow, M. E. \& Tilghman, S. M. Epigenetic mechanisms underlying the imprinting of the mouse $\mathrm{H} 19$ gene. Genes Dev. 7, 1663-1673 (1993) | Ferguson-Smith, A. C., Sasaki, H.,

Cattanach, B. M. \& Surani, M. A. Parental-origin-specific epigenetic modification of the mouse $\mathrm{H} 19$ gene. Nature $\mathbf{3 6 2}$ 751-755 (1993) | Reis, A. et al. Imprinting mutations suggested by abnormal DNA methylation patterns in familial Angelman and Prader-Willi syndromes. Am. J. Hum. Genet. 54, 733-740 (1994) | Sutcliffe, J. S. et al. Deletions of a differentially methylated $\mathrm{CpG}$ island at the SNRPN gene define a putative imprinting control region. Nature Genet. 8, 52-58 (1994)

\title{
The importance of wrapping
}

Nucleosomes are the basic building blocks of the eukaryotic nucleus, packaging DNA into the chromatin of individual chromosomes. The nucleosome consists of a histone octamer - a tetramer of histones $\mathrm{H} 3-\mathrm{H} 4$ and two dimers of histones $\mathrm{H} 2 \mathrm{~A}-$ $\mathrm{H} 2 \mathrm{~B}$ - around which the DNA string is wrapped approximately 1.8 times.

In vitro studies in the late 1970 s with Escherichia coli RNA polymerase on bacteriophage DNA showed that transcription can proceed through regions of DNA organized into nucleosomes. Subsequent in vitro findings were to reveal that the transcription of other DNA templates was repressed by histones, especially when nucleosome density was increased. However, many believed that chromatin was transparent to RNA polymerase in living cells. Therefore, the idea that nucleosomes might be regulating gene transcription was generally dismissed by scientists in the 1980s, who were preoccupied with the ever-growing list of cis-acting sequences and associated factors that controlled gene transcription.

An important hint that nucleosomes had a function other than packaging DNA came from Kornberg and colleagues, who found that nucleosomes assembling on gene promoters would themselves block initiation of transcription in vitro.

Scientists, however, remained sceptical and continued to ignore chromatin until a year later, when Han and Grunstein showed that nucleosome loss, through histone depletion, resulted in the increased transcription of numerous genes in yeast. This provided the first in vivo evidence that nucleosomes can repress gene activity. So, as interest grew in understanding how they regulated transcription, nucleosomes found themselves back in the test tube, with their individual histone components being chopped up and examined.

The Grunstein group laid the first cornerstone by showing that histone tails had specific functions. Studies on histone $\mathrm{H} 4$ revealed that its tail is dispensable for yeast growth, but is required to repress the activation of specific mating loci through the binding of a repressor protein. The same group showed that the $\mathrm{H} 4$ tail also had a gene-activating function and that histone modifications - namely acetylation at specific residues - were required for gene

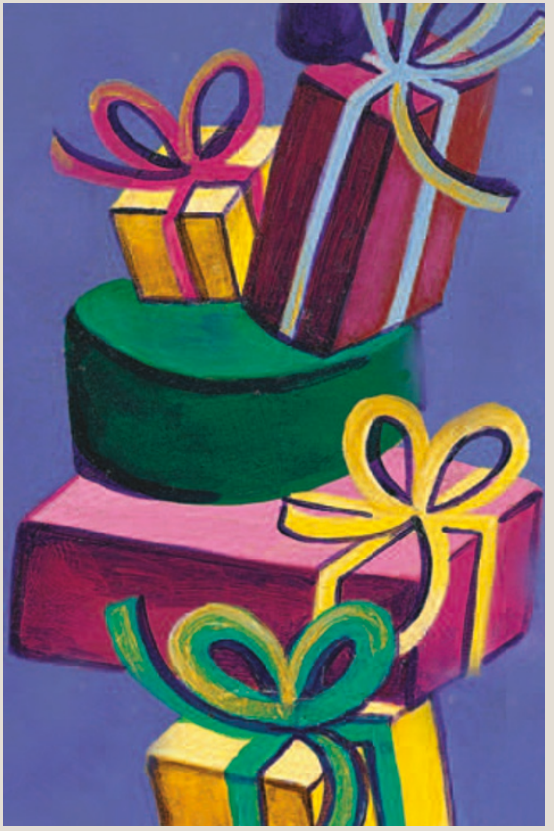

transcription. Now, of course, the posttranslational modification of histone tails and their binding to regulatory proteins is a fundamental theme in transcriptional regulation (see Milestones 19 and 22).

So, what was once considered 'cellophane wrapping' now constitutes the 'nuts and bolts' of the transcription-regulatory apparatus. Science and the persistence of certain visionaries has once again proved that appearances can be deceptive, and that you might have to dig a little deeper and stare a little longer to uncover the function that lies at the core.

Myrto Raftopoulou

Associate Editor, Nature Cell Biology

\section{References and links}

ORIGINAL RESEARCH PAPERS Lorch, Y., LaPointe, J. W. \& Kornberg, R. D. Nucleosomes inhibit the initiation of transcription but allow chain elongation with displacement of histones. Cell 49, 203-210 (1987) | Han, M. \& Grunstein, M. Nucleosome loss activates yeast down-stream promoters in vivo. Cell 55, 1137-1145 (1988) | Kayne, P. S. et al. Extremely conserved histone $\mathrm{H} 4 \mathrm{~N}$-terminus is dispensable for growth but essential for repressing the silent mating loci in yeast. Cel/55, 27-39 (1988)| Durrin, L. K., Mann, R. K., Kayne, P. S. \& Grunstein, M. Yeast histone H4-N-terminal sequence is required for promoter activation in vivo. Cell 65 1023-1031 (1991)

FURTHER READING Allfrey, V., Littau, V. C. \& Mirsky, A. On the role of histones in regulation ribonucleic acid synthesis in the cell nucleus. Proc. Natl Acad. Sci. USA 49, 414-421 (1963) | Han, M., Kim, U. J., Kayne, P. \& Grunstein, M. Depletion of histone $\mathrm{H} 4$ and nucleosomes activates the PHO5 gene in Saccharomyces cerevisiae. EMBO J. 7 2221-2228 (1988) | Laybourn, P. J. \& Kadonaga, J. T. Role of nucleosomal cores and histone $\mathrm{H} 1$ in regulation of transcription by RNA polymerase II. Science 254 238-245 (1991) 